\title{
トウモロコシの生育に及ぼす高温処理の影響
}

\section{Effects of high daytime temperature on the growth of sweet corn (Zea mays L.)}

長屋祐一 ${ }^{*}$, 谷山鉄郎 ${ }^{* *}$, 安藤文章 ${ }^{* *}$, 鈴木康正 ${ }^{* *}$, 梅崎輝尚 ${ }^{*}$

Yuichi Nagaya*,Tetsuro Taniyama**, Fumiaki Ando**, Yasumasa Suzuki** and Teruhisa Umezaki*

キーワード : トウモロコシ, 温暖化, 食糧生産, 高昼温

\section{1.はじめに}

地球温暖化の予測は, 経済成長速度とグローバ ル化の進展度合を組合せた排出シナリオによって 大きく異なる。日本の平均気温は, 20 世紀末 $(1980$ 〜 1999 年) から 21 世紀末 $(2090$ ～ 2099 年) まで に, シナリオ $\mathrm{A} 2$ で $4.0^{\circ} \mathrm{C}$, シナリオ $\mathrm{A} 1 \mathrm{~B}$ で $3.2^{\circ} \mathrm{C}$, シナリオ $\mathrm{B} 1$ で $2.1^{\circ} \mathrm{C}$ 上昇し，いずれのシナリオで も世界の平均 $\left(3.4^{\circ} \mathrm{C}, 2.8^{\circ} \mathrm{C}, 1.8^{\circ} \mathrm{C}\right)$ を上回ると予 測された（文部科学省ら, 2009）。この報告による と, 気温が $4^{\circ} \mathrm{C}$ 以上の上昇がみられた場合には, 降 水量の増加, ブナ林の減少, 松枯れの増加など気 象や生態系に及ぼす影響が大きい。代表的な農作 物である水稲の収量も減少し, リンゴやウンシュ ウミカンの栽培不適地の増加が示唆されている。

人間の食糧や家畜の飼料として利用する主要な 作物は, コムギ, イネ, トウモロコシである。ト ウモロコシは温帯の暖かい地方から湿潤な亜熱帯 まで広く栽培され, 栽培面積はコムギ, 水稲につ いで世界第 3 位を占める。トウモロコシは子実用 のほか, 生食・加工用, 青刈りやサイレージ用と して栽培されている（高崎，1999）。

作物の生長は栄養生長から生殖生長へ移行ある
いは並進して成熟する。作物の収量は全乾物重あ るいは地上部乾物重とこれらに占める収穫部位の 割合との積であることから, 作物に及ぼす適温を 超える高温の影響は, 生育経過, 全乾物重, 地上 部乾物重などに現れると考えられる。トウモロコ シは子実のみならず青刈も利用可能であることか ら，生育経過や乾物重に及ぼす温暖化の影響につ いて調査することは, 食糧や飼料の確保から重要 である。

そこで, 本報告では, トウモロコシの栽培につい て最適温度が $30^{\circ} \mathrm{C}$ から $32^{\circ} \mathrm{C}$ である（丹下，1973） ことから昼温を $31^{\circ} \mathrm{C}$ とた標準区と, これより $4^{\circ} \mathrm{C}$ 高い昼温（高温区）を設定し,トウモロコシの 生育と部位別乾物重, 葉面積に及ぼす高昼温の影 響について検討した。

\section{2. 材料と方法}

供試品種はトウモロコシの一代交配品種である 甘味種を 2 品種（カラフルコーン, サニーショ コラ）用いた。供試材料は, 8 号のプラスチック ポット（容量８リットル）に, 赤玉土をポットの 底に $1 \mathrm{~kg}$ 敷き, 未耕砂質土壤 $3 \mathrm{~kg}$ とゴールデン堆 肥 $1 \mathrm{~kg}$, 基肥として化成肥料 $\left(\mathrm{N}: \mathrm{P}_{2} \mathrm{O}_{5}: \mathrm{K}_{2} \mathrm{O}=8: 8: 8\right)$

*三重大学大学院生物資源学研究科（） $514-8507$ 津市栗真町屋町 1577)

**中部大学応用生物学部 ( T 487-8501 春日井市松本町 1200)

*Graduate School of Bioresources, Mie University (1577 Kurimamachiya, Tsu, Mie, 514-8507, Japan)

E-mail nagaya@bio.mie-u.ac.jp

連絡責任者：長屋祐一（nagaya@bio.mie-u.ac.jp）

${ }^{* *}$ College of Bioscience and Biotechnology, Chubu University (1200 Matsumoto-cho, Kasugai, Aichi, 487-8501, Japan) 
$4.36 \mathrm{~g}$ を混和充填した。生育のそろった 2 週間苗を 8 号のプラスチックポットに 1 個体定植した。カ ラフルコーンの播種日は 2009 年 3 月 19 日, 追肥 は 5 月 3 日（播種後 45 日目）と 5 月 24 日（播種 後 66 日目), サンプリングは 6 月 11 日（播種後 84 日目) であった。サニーショコラの播種日は 2009 年 10 月 5 日, 追肥は 11 月 6 日（播種後 32 日目）, サンプリングは 11 月 18 日（播種後 44 日目）で あった。追肥は前述の化成肥料を 1 回につき $2.35 \mathrm{~g}$ 施用した。

栽培条件は 2 基の人工光型グロースキャビネッ 卜 (小糸製作所, $\mathrm{KG}$ - V64 型) を用いて, それぞ れ高温区（昼温 $35^{\circ} \mathrm{C}, 6$ 時から 19 時 /夜温 $25^{\circ} \mathrm{C}$, 19 時から 6 時) と標準区（昼温 $31^{\circ} \mathrm{C}, 6$ 時から 19 時 /夜温 $25^{\circ} \mathrm{C}, 19$ 時から 6 時) の 2 処理とし た。人工光型グロースキャビネットの相対湿度は 常時 $60 \%$ とした。また, 明期の光量は, 室内高 $150 \mathrm{~cm}$ でラインセンサ $(80 \mathrm{~cm})$ 光量子計 (Decagon, SUNFLECK CEPTOMETER) によって $630 \mu$ $\mathrm{mol} / \mathrm{m}^{2} / \mathrm{s}$ であった。明一暗期の温度変化は, 明期 の始期と終期の 2 時間をかけて, 一定の割合で設 定温度に変化するよう調節した。

各処理は人工光型グロースキャビネット内に 15 個体を設置した。それぞれの個体は室内環境の 影響が少なくなるよう毎週場所を移動し, 潅水は 適宜行った。

草高は播種後 14 日目から 7 日ごと測定した。葉 数は個体に着生した葉身のうち緑色部分が $70 \%$ 以上のものを対象に, カラフルコーンは播種後 35 日目から, サニーショコラは播種後 14 日目から 7 日ごと測定した。

サンプリングについて, カラフルコーンは播種 後 84 日目, サニーショコラは播種後 42 日目に 行った。まず地際から刚取り, 地上部は葉身, 雄 穂, 雌穂に切り分け, 地下部は土壤を洗い落とし, その後, 通風乾燥機によって $80^{\circ} \mathrm{C} て ゙$ 恒量になるま で乾燥させ部位別乾物重を計測した。葉面積はサ ンプリング後に葉身部分を対象として自動面積計 （林電工, AAM-9）にて測定した。地上部乾物重 と地下部乾物重の比率である TR 率を算出した。

処理区間の比較はエクセル統計 2004 (社会情報 サービス）を利用し， t 検定にて行った。

\section{3. 結果}

カラフルコーンの草高について, 播種後 21 日 目に高温区が標準区と比較して $5 \%$ 水準で有意に 高かったが, 播種後 28 日目以降では高温区が標 準区と比較して $1 \%$ 水準で有意に低かった。播種 後 42 日目には全ての個体で雄穂抽出期に達した。 両処理区とも播種後 56 日目以降の草高はほぼ一 定であった（図 1)。高温区の葉数は播種後 49 日 目，77日目，84 日目を除いて標準区より $5 \%$ 水準 で有意に少なく推移した（図 2)。登熟期の播種後 84 日目にサンプリングを行い, 部位別に分けて乾 物重を測定した。茎 (秙+葉鞘) 乾物重, 雄穂乾 物重, 地上部 $($ 葉身 + 秙 + 葉鞘 + 雄穂 + 雌穂 $)$ 乾 物重, 地下部 (根+稈) 乾物重および葉面積につ いて, いずれも高温区は標準区より1\%水準で有 意に小さくなった。葉身乾物重, 雌穂乾物重およ びTR 率は, 処理区間に有意差はみられなかった (表 1)。

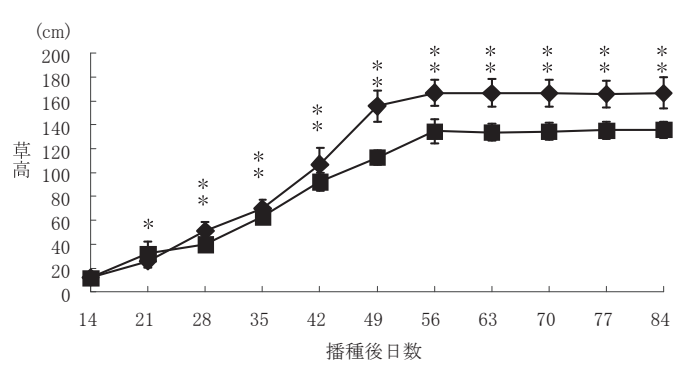

図 1. 草高の推移（カラフルコーン）

; 高温区, ; 標準区. 縦棒は標準偏差 $(n=15)$ を 示す。*は $5 \%, * *$ * $1 \%$ 水準で有意差がある。

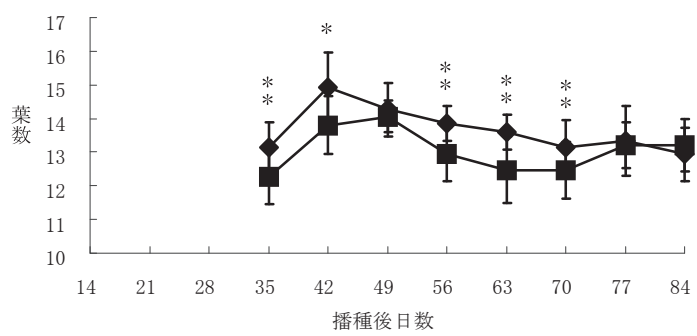

図 2. 緑色割合が $70 \%$ 以上の葉数（カラフルコーン）

; 高温区, ; 標準区. 縦棒は標準偏差 $(n=15)$ を 示す。*は $5 \%, * *$ * $1 \%$ 水準で有意差がある。 
表 1 . 部位別乾物重と葉面積, TR 率 (カラフルコーン)

\begin{tabular}{|c|c|c|c|c|}
\hline & $\begin{array}{c}\text { 葉身乾物重 } \\
\text { (g) }\end{array}$ & $\begin{array}{c}\text { 茥(秙+葉鞘) } \\
\text { 乾物重 } \\
(\mathrm{g})\end{array}$ & $\begin{array}{c}\text { 雄穂乾物重 } \\
(\mathrm{g})\end{array}$ & $\begin{array}{c}\text { 雌穂乾物重 } \\
\text { (g) }\end{array}$ \\
\hline 高温区 & $18.6 \pm 1.8$ & $84.5 \pm 12.3$ & $7.0 \pm 1.1$ & $11.3 \pm 5.6$ \\
\hline 標準区 & $19.6 \pm 2.6$ & $124.8 \pm 13.1$ & $8.9 \pm 1.6$ & $15.5 \pm 8.1$ \\
\hline & $\begin{array}{c}\text { 地上部(葉身+ } \\
\text { 葉鞘+稈+雄 } \\
\text { 穂十雌穂) 乾物 } \\
\text { (g) }\end{array}$ & $\begin{array}{c}\text { 地下部 (根+ } \\
\text { 稈) 乾物重 } \\
(\mathrm{g})\end{array}$ & $\begin{array}{l}\text { 葉面積 } \\
\left(\mathrm{cm}^{2}\right)\end{array}$ & TR率 \\
\hline 高温区 & $121.3 \pm 11.5$ & $7.4 \pm 1.3$ & $2173 \pm 194$ & $16.6 \pm 2.5$ \\
\hline $\begin{array}{l}\text { 標準区 } \\
\text { 有意差 }\end{array}$ & $\begin{array}{c}168.9 \pm 12.8 \\
* *\end{array}$ & $\begin{array}{c}10.9 \pm 1.8 \\
* *\end{array}$ & $\begin{array}{c}2492 \pm 283 \\
\text { ** }\end{array}$ & $16.0 \pm 3.4$ \\
\hline
\end{tabular}

サニーショコラの草高について, 播種後 28 日目 を除き，高温区が標準区と比較して $5 \%$ 水準で有 意に低かった(図 3)。葉数は 35 日目まで両処理区 とも同様に推移し, 播種後 42 日目には高温区が標 準区より $1 \%$ 水準で有意に多くなった（図 4）。全 ての個体で雄穂抽出期に達した播種後 42 日目に サンプリングを行い，部位別に分けて乾物重を測 定した。茎 (稈 + 葉鞘 + 雌穂 $)$ 乾物重, 雄穂乾物 重, 地上部 $($ 葉身 + 㷏 + 葉鞘 + 雄穂 + 雌穂 $)$ 乾物 重および地下部（根＋程）乾物重について，いず れも高温区は標準区より $1 \%$ 水準で有意に小さく なった。高温区の葉面積は, 標準区より $5 \%$ 水準

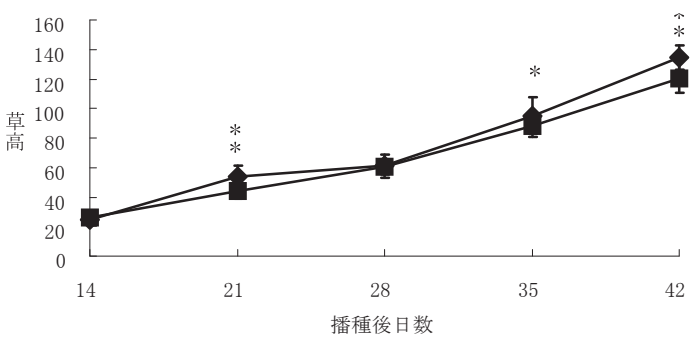

図 3. 草高の推移（サニーショコラ）

; 高温区、 ; 標準区。縦軸は標準偏差 $(n=15)$ を 示す。*は $5 \%$, **は $1 \%$ 水準で有意差がある。

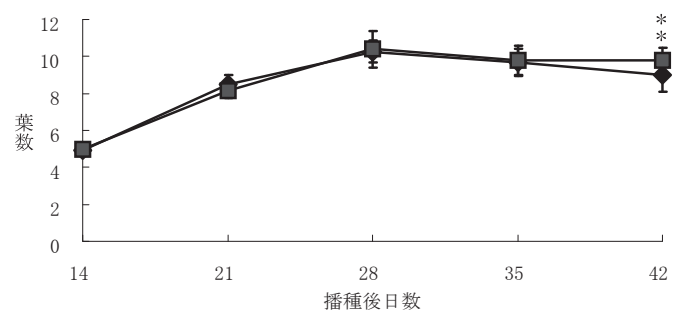

図 4. 緑色割合が $70 \%$ 以上の葉数（サニーショコラ）

；高温区， ; 標準区. 縦軸は標準偏差 $(n=15)$ を 示す。**は $1 \%$ 水準で有意差がある。
で有意に小さくなった。葉身乾物重および TR 率 は，処理区間に有意差はみられなかった（表 2)。

また，両品種とも人工光型グロースキャビネッ 卜内で栽培した高温区のトウモロコシは，標準区 と比較して葉身の葉焼け, 雄穂の開葯不良などが 観察された。

表 2 . 部位別乾物重と葉面積, TR 率（サニーショコラ）

\begin{tabular}{|c|c|c|c|c|}
\hline $\begin{array}{l}\text { 高温区 } \\
\text { 標準区 } \\
\text { 有意差 } \\
\end{array}$ & $\begin{array}{c}\text { 葉身乾物重 } \\
(\mathrm{g}) \\
9.7 \pm 1.0 \\
10.4 \pm 1.2\end{array}$ & $\begin{array}{c}\begin{array}{c}\text { 茥(秙+葉鞘 } \\
\text { +雌穂) 乾物重 } \\
(\mathrm{g})\end{array} \\
20.9 \pm 7.1 \\
45.3 \pm 11.6 \\
* * \\
\end{array}$ & $\begin{array}{c}\text { 雄穂乾物重 } \\
(\mathrm{g}) \\
6.0 \pm 1.3 \\
7.5 \pm 1.4 \\
\text { *** } \\
\end{array}$ & \\
\hline & $\begin{array}{c}\text { 地上部(葉身+ } \\
\text { 葉鞘+稈+雄 } \\
\text { 穂＋雌穂) 乾物 } \\
(\mathrm{g}) \\
\end{array}$ & $\begin{array}{c}\text { 地下部 (根+ } \\
\text { 稈) 乾物重 } \\
(\mathrm{g})\end{array}$ & $\begin{array}{c}\text { 葉面積 } \\
\left(\mathrm{cm}^{2}\right) \\
\end{array}$ & TR率 \\
\hline $\begin{array}{l}\text { 高温区 } \\
\text { 標隻区 } \\
\text { 有意差 }\end{array}$ & $\begin{array}{c}36.6 \pm 7.1 \\
63.1 \pm 12.9 \\
* *\end{array}$ & $\begin{array}{r}8.1 \pm 2.9 \\
16.6 \pm 4.4 \\
* *\end{array}$ & $\begin{array}{c}1919 \pm 220 \\
2122 \pm 380 \\
*\end{array}$ & $\begin{array}{l}4.9 \pm 1.4 \\
4.2 \pm 1.7\end{array}$ \\
\hline
\end{tabular}

\section{4. 考察}

トウモロコシの生育に及ぼす高昼温の影響につ いて 2 品種を用いて検討した結果, 両品種とも草 高は高温区が標準区より低く推移した（図 1, 図 3)。草高が最高位に達するまでは草高と乾物重は 比例して大きくなることから, 雄穂抽出期を過ぎ てサンプリングしたサニーショコラでは茥乾物 重, 雄穂乾物重, 地上部乾物重, 地下部乾物重に ついて高温区が標準区より小さくなった（表 2）。 登熟期まで栽培したカラフルコーンは, 雄穂抽出 期を過ぎて草高が一定となって推移したが, サン プリング時における茥乾物重, 雄穂乾物重, 地上 部乾物重, 地下部乾物重について高温区が標準区 より小さくなった（表 1)。以上のことから高温区 の部位別乾物重の減少は, 両品種で共通してみら れた。

植物は光合成作用と呼吸作用の差引きによって 光合成産物を蓄積し, 乾物重が増加する（窪田, 1999)。トウモロコシの主要な光合成作用は葉身 部分で行われ, 葉面積と単位面積あたりの光合成 速度の積で概算される。トウモロコシ葉身の着生 状況について, 光合成を行う緑色部分が葉身全体 の 7 割以上ある葉数を計測したところ, カラフル コーンでは高温区が標準区より概して少なく（図 2)，また葉面積ならびに葉身乾物重についても高 


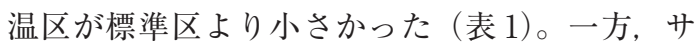
ニーショコラは葉数についてほぼ同様であった が, 葉面積ならびに葉身乾物重については高温区 が標準区より小さかった（表 2)。両品種の栽培期 間は異なるが，共通して高昼温により葉身の面積 および乾物重が減少した。高温区では人工光源に 近い葉身の一部が白くなるものが見られたことか ら, 高温と強光により葉緑体の壊死が生じること により, 光合成の場である葉身の葉面積が標準区 より減少すると考えられた。

Ben-Asher et al.（2008）は，昼温／夜温を変え てポット栽培したトウモロコシの葉身について個 葉光合成活性を測定したところ, $40^{\circ} \mathrm{C} / 35^{\circ} \mathrm{C}$ で栽 培したトウモロコシの真の光合成速度は $25^{\circ} \mathrm{C} /$ $20^{\circ} \mathrm{C}$ の 50 〜 $60 \%$ 程度と低くなったと報告した。 Murata et al. (1965) は, トウモロコシの幼植物を 用いて個体の真の光合成速度に及ぼす気温の影響 について検討したところ, $30 \sim 35^{\circ} \mathrm{C}$ までは同程度 で, $35^{\circ} \mathrm{C}$ 以上になると低下すると報告した。よって トゥモロコシは昼温が $35^{\circ} \mathrm{C}$ 以上になると光合成 速度が低下すると思われる。一般に光合成速度は, 光量, 気温, 湿度, 植物体の水分状態, 栄養状態 などの要因に影響される。本報告では, 昼温は異 なるが相対湿度 $60 \%$ 条件下での栽培を行った。昼 温が $35^{\circ} \mathrm{C}$ の飽差は $31^{\circ} \mathrm{C}$ よ大きいので蒸散量が 大きくなると考えられる。水稲の生育や光合成速 度に及ぼす湿度の影響については平井ら（1989）, 平井ら（1993）の報告があるが，トウモロコシに 及ぼす湿度の影響について詳細な検討がなされて いないことから, 高昼温に及ぼす湿度の影響につ いては今後の課題である。

本報告では栽培期間が異なる供試材料を用いた が，両者ともに高昼温により乾物重の低下がみら れた（表 1 , 表 2) ことから, 高昼温によってトウ モロコシの光合成速度は低下し, 葉面積が減少す ることにより全体の光合成作用が低下したため, 乾物重が低下したと推測された。また地上部と地 下部の比率を示す TR 率には高温の影響がみられ なかった（表 1 , 表 2 ）ことから, 乾物重の蓄積は 気温の違いに関わらず地上部, 地下部ともに同じ 程度に蓄積すると思われた。

トウモロコシの利用形態は完熟した子実のほ か, 子実が完熟する前の生食・加工あるいは地上
部全てを対象とした青刈り状態で利用可能である (高崎, 1999)。食糧や飼料として利用可能な完熟 した子実について, 高昼温により乾物重が低下す ることで, 子実重も同様に減少することが予想さ れる。一方で, 子実は雄穂の花粉が風媒によって 運ばれ受精した後, 光合成産物の転流が開始され 発育する（高崎, 1999）。本報告の高温区では両品 種ともに雄穂の葯に開花不良がみられたため, 高 温処理によって不稔の子実が増加すると予想され る。したがって, 乾物重の低下と不稔の増加によ り, 高温処理により子実重の減少が予想された。

高温ストレスは植物の生長適温を上回る程度の 高温下で生育した場合に現れるストレスである。 この高温ストレスは, 高温が生育適温からどれく らい上回る温度なのかと接触する時期と期間に よって障害の現れ方が異なる（伊藤，1994）。本 報告では全生育期間について昼温の高温処理を行 い, 栄養生長と生殖生長の双方に負の効果がみら れた。温暖化によって今後予想される気温の上昇 は, 昼温だけでなく夜温の上昇も考えられること から, 夜温の上昇も考慮した高温の影響について, さらに検討を続ける必要がある。

\section{引用文献}

Ben-Asher, J., A. Garcia Y Garcia \& G. Hoogenboom (2008) Effect of high temperature on photosynthesis and transpiration of sweet corn (Zea mays L. var. rugosa), Photosynthetica 46 (4), 595-603.

平井源一 - 中山 登・北宅善昭 · 稲野藤一郎 - 中條 博良・湊 公美・田中 修 (1989) 大気湿度が水 稲の生育ならびに生理に及ぼす影響 : 第 6 報 大 気湿度が水稲模擬個体群の光合成速度に及ぼす 影響，日作紀，58（3）, 368-373.

平井源一 - 中條博良 - 田中 修 - 奥村俊勝 - 竹内史 郎・平野高司・大森雅代（1993）大気湿度が水 稲生育ならびに生理に及ぼす影響 : 第 8 報 種々 の気温における幼植物の乾物生産と窒素吸収に 及ぼす大気湿度の影響, 日作紀, 62（3）, 395400.

伊藤亮一（1994）6. 塩・温度ストレスと作物の生

長, 植物生産生理学, 132-144, 朝倉書店.

窪田文武 (1999) 7. 品種改良の目標と生理生態的 
形質, 作物学総論, 143-161, 朝倉書店.

文部科学省・気象庁・環境省 (2009）温暖化の観

測・予測及び影響評価統合レポート「日本の気

候変動とその影響」, 25-45.

Murata, Y., J. Iyama \& T. Honma (1965)

Studies on the Photosynthesis of Forage Crops

: IV. Influence of air-temperature upon the photosynthesis and respiration of alfalfa and several southern type forage crops. Proc. Crop Sci. Soc. Japan, 34,154-158.

高崎康夫（1999）1.7 トゥモロコシ, 作物学各論, 38-48, 朝倉書店.

丹下宗俊（1973） 1. 気象条件, $\mathrm{V}$ 環境, 作物学, 137-154, 朝倉書店. 